\title{
The ecological impact of using photothermal and photovoltaic installations for DHW preparation
}

AbSTRACT: A domestic hot water (DHW) system has been modernized in a multi-family house, located in the southeastern part of Poland, inhabited by 105 people. The existing heating system ( 2 gas boilers) was extended by a solar system consisting of 32 evacuated tube collectors with a heat pipe (the absorber area: $38.72 \mathrm{~m}^{2}$ ). On the basis of the system performance data, the ecological effect of the modernization, expressed in avoided $\mathrm{CO}_{2}$ emission, was estimated. The use of the solar thermal system allows $\mathrm{CO}_{2}$ emissions to be reduced up to $4.4 \mathrm{Mg}$ annually. When analyzing the environmental effects of the application of the solar system, the production cycle of the most material-consuming components, namely: DHW storage tank and solar collectors, was taken into account. To further reduce $\mathrm{CO}_{2}$ emission, a photovoltaic installation (PV), supplying electric power to the pump-control system of the solar thermal system has been proposed.

In the Matlab computing environment, based on the solar installation measurement data and the data of the total radiation intensity measurement, the area of photovoltaic panels and battery capacity has been optimized. It has been shown that the photovoltaic panel of approx. $1.8 \mathrm{~m}^{2}$ and $12 \mathrm{~V}$

$\triangle$ Corresponding Author: Piotr Olczak; e-mail: olczak@min-pan.krakow.pl

1 Mineral and Energy Economy Research Institute, Polish Academy of Sciences, Kraków, Poland; ORCID iD: 0000-0002-4926-0845; e-mail: olczak@min-pan.krakow.pl

${ }^{2}$ Faculty of Environmental and Energy Engineering, Cracow University of Technology, Kraków, Poland; e-mail: molek@pk.edu.pl

3 Mineral and Energy Economy Research Institute, Polish Academy of Sciences, Kraków, Poland; ORCID iD: 0000-0003-0639-3485; e-mail: kryzia@min-pan.krakow.pl

2020. The Author(s). This is an open-access article distributed under the terms of the Creative Commons Attribution-ShareAlike International License (CC BY-SA 4.0, http://creativecommons.org/licenses/by-sa/4.0/), which permits use, distribution, and reproduction in any medium, provided that the Article is properly cited. 
battery capacity of approx. $21 \mathrm{Ah}$ gives the greatest ecological effects in the form of the lowest $\mathrm{CO}_{2}$ emission. If a photovoltaic system was added it could reduce emissions by up to an additional $160 \mathrm{~kg}$ per year. The above calculations take also emissions resulting from the production of PV panels and batteries into account.

Keywords: photovoltaic panel, reduction of $\mathrm{CO}_{2}$ emission, evacuated tube collector with heat pipe

\section{Introduction}

In Poland the microgeneration is the alternative for decreasing greenhouse gases emission from the housing sector (IEO and ZP FEO 2013). This applies, among others, two forms of solar energy: photothermal and photovoltaic conversion (Carotenuto 2017). Under low solar irradiation prevailing in Poland, thermal installations are mainly used for heating domestic hot water (DHW). This allows the use of fossil fuels to prepare DHW to be reduced and thus allows the emission of gaseous and particulate matter pollutants into the atmosphere to be reduced, particularly during the summer period (Mirowski 2016). In Polish conditions, the majority of solar installations are equipped with solar controllers and additional pumps, the aim of which is to help with the heat transport. Both devices are electrically powered. In Poland, $76.8 \%$ of electricity is generated in coal power plants (Statistics Poland 2019). Currently, the average $\mathrm{CO}_{2}$ emission factor (Ec) of the Polish energy sector is $0.765 \mathrm{~kg} / \mathrm{kWh}$ while the average emission factor foreseen (Ef) for the years 2019-2035 is $0.74 \mathrm{~kg} / \mathrm{kWh}$ (Gawlik 2013; The National Center 2019). Upgrading the thermal system with the addition of PV panels generating energy that supplies the pump-control system allows the consumption of electricity produced from fossil fuels (mainly coal) to be reduced.

The aim of the study was to estimate the annual ecological impact on existing hybrid system supplied by 2 gas boilers and 32 solar collectors. On the basis of data on the amount of fuel saved and materials used for the production of the main components of the solar system, a comparative analysis of $\mathrm{CO}_{2}$ emission has been performed. To further reduce $\mathrm{CO}_{2}$ emissions, a photovoltaic installation (PV) with annual average efficiency 15\% (Sornek 2018), supplying electric power to the pump-control system of the solar thermal system, has been proposed. Based on the measurements of operating parameters of the system in a multi-family house and the intensity of solar radiation (Fig. 1), the power of a PV panel and battery capacity, providing the lowest $\mathrm{CO}_{2}$ emissions, has been determined. 


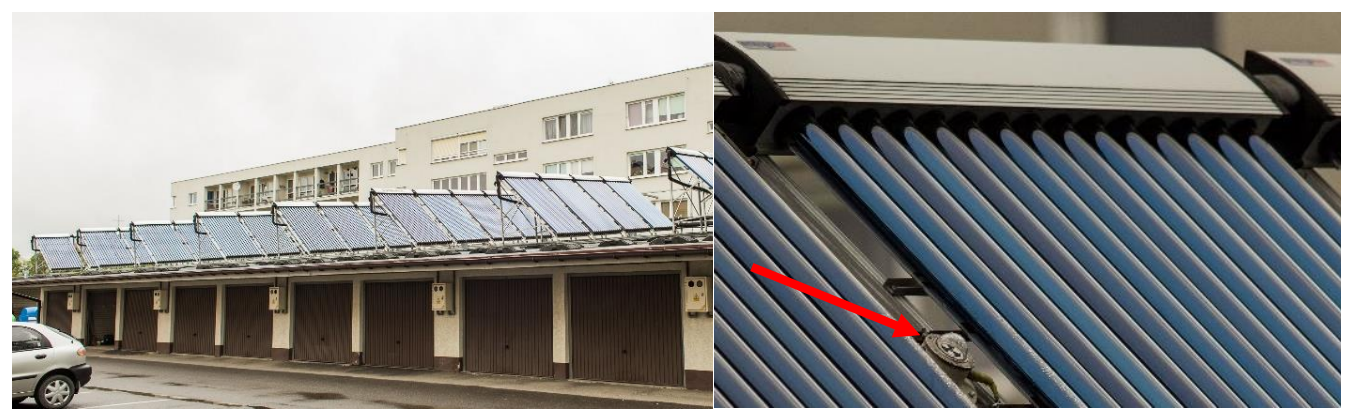

Fig. 1. Installation - left side, pyranometer mounted between pipes - right side Source: own study

Rys. 1. Instalacja - lewa strona, pyranometr montowany między rurami kolektorów - prawa strona

\section{Methodology}

The analysis was performed for an existing hybrid system used for central heating and domestic hot water preparation (Fig. 2). The daily demand for hot water is $4.5 \mathrm{~m}^{3}$ with the temperature in the range from 3 to $17^{\circ} \mathrm{C}$ at the inlet and $55^{\circ} \mathrm{C}$ at the outlet of the installation. The heat source are 2 gas boilers ( $130 \mathrm{~kW}$, Viessmann Paromat Triplex Boiler) with a nominal efficiency of $94 \%$ and a set of 32 evacuated tube collectors with heat pipe (ETCHP), (Energosol HP-15R) (ENERGOSOL 2017). The total area of absorbers is $38.72 \mathrm{~m}^{2}$. The installation for heating DHW is equipped with two storage tanks with a total capacity of $1,000 \mathrm{dm}^{3}$ (GT1 and GT2) and two solar storage tanks with a total capacity of 3,000 $\mathrm{dm}^{3}$ (ST1 and ST2). Both ST are made of steel and insulating material made of hard polyurethane foam with a thickness of $70 \mathrm{~mm}$.

The heating system is shown in Figure 2 and the operating principle is described by (Olczak and Zabagło 2015). The heat transfer medium circulating between the ETCHP and the storage tanks is a water/glycol mixture. The power of installed solar pumping system is $75 \mathrm{~W}$. The solar system is fitted with five temperature sensors. The operation of the system is controlled by a Steca TR $0603 \mathrm{mc}$ solar thermal controller with a maximum power of $2 \mathrm{~W}$, which collects temperature data and operation time of the pump at 1-minute intervals. The monthly total solar yield is measured by a CF Echo II heat meter, while the solar radiation available on the collector surface is measured using an Eppley Pyranometer.

The avoided $\mathrm{CO}_{2}$ emission resulting from the extension of the central heating and DHW preparation system with the addition of the thermal solar system was estimated from the general formula (1): 


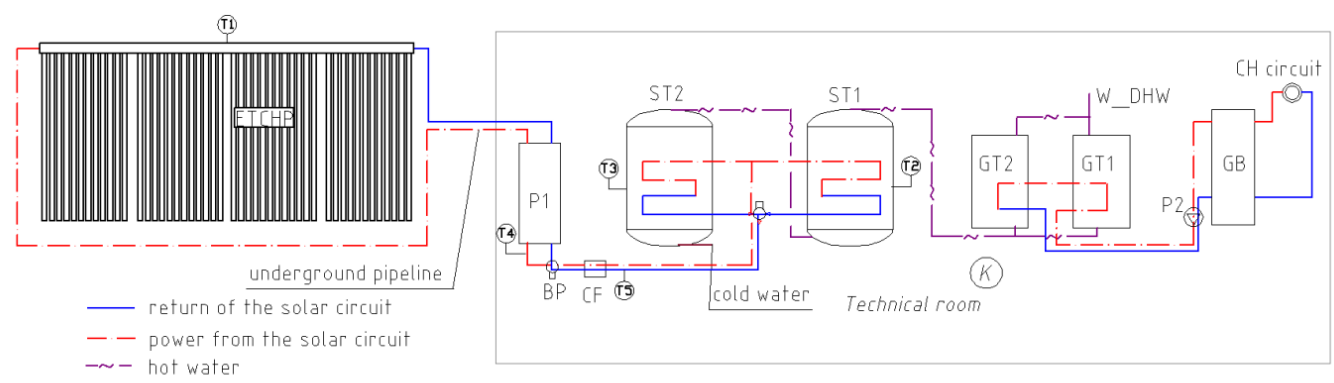

- - hot water

- cold water

Fig. 2. Installation scheme: GT1 and GT2 - storage tanks supplied by gas boilers; GB - gas boiler; W_DHW - DHW outlet to the building; $\mathrm{CH}$ - the central heating circuit, P1 - solar circulation pump; P2 - boiler circulation pump; ST1 and ST2 - solar storage tanks, ETCHP - 15 tube evacuated tube collectors; BP - by-pass; CF - heat meter; $\mathrm{T} 1 \ldots 5$ - temperature sensors; $\mathrm{CW}$ - cold water inlet Source: own study

Rys. 2. Schemat instalacji: GT1 i GT2 - zasobniki ciepłej wody użytkowej zasilane z kotłów gazowych; GB - kocioł gazowy; W_DHW - zasilanie budynku w ciepła wodę użytkową; CO - obieg CO, P1 - solarna pompa obiegowa;

P2 - pompa obiegowa kotła; ST1 i ST2 - zasobnik ciepłej wody użytkowej zasilany z instalacji kolektorów słonecznych, ETCHP - 15 rurowych kolektorów próżniowych; BP - by-pass; CF - licznik ciepła; T1...5 - czujniki temperatury; $\mathrm{CW}$ - ujęcie zimnej wody

reduction of $\mathrm{CO}_{2}$ emission $=f$ (the demand for heat for $\mathrm{DHW}$, saved natural gas, emission during the production of the system components expressed as equivalent of $\mathrm{CO}_{2}$ )

In the analysis used data of pump run time (PRT), time ST1 or ST2 recharge (RT), solar heat gains from 2013 (SY13), which resembles the average solar heat gains during the system operation in the period of X.2011 - IX.2015 (SY11_15) (Table 1). As a result of the expansion of the heating system by renewable energy sources (Table 1) for the preparation of DHW, reduction in natural gas consumption from $11,800 \mathrm{~m}^{3}$ to $9,280 \mathrm{~m}^{3}$, has been stated. Assuming the $\mathrm{CO}_{2}$ emission factor for the combustion of gas at a level of $2 \mathrm{~kg} / \mathrm{m}^{3}$ (The National Center 2015) the avoided $\mathrm{CO}_{2}$ emission was determined. This value is diminished by the amount of $\mathrm{CO}_{2}$ emission resulting from the operation of the pump-control system powered by electric power. The abovementioned emission was estimated on the basis of the pump power, the control system power, and the operation time (Table 1), the efficiency of energy conversion in power plant (38\%), the losses in electricity transmission (7.3\%) (BBN 2012), energy losses of the power plant (10\%) and factor Ec $(0.765 \mathrm{~kg} / \mathrm{kWh})$.

The measured annual solar yield amounted to 92.84 GJ. Since the heat meter is suitable for temperature measurements of water, and the solar system is filled with water/glycol mixture, solar yields were adjusted according to the average monthly temperature (Table 1). The adjusted solar yield amounted to $82.94 \mathrm{GJ}$.

Other factors reducing the positive ecological effect are materials used for the construction of the installation and the energy required for their production. The analysis took the three heaviest 
TABLE 1. The measurement results obtained in 2013 and average values from 10/ 2011 to 9/2015

TABELA 1. Wyniki pomiarów uzyskane w 2013 roku oraz średnie wartości dla okresu od X 2011 do IX 2015

\begin{tabular}{|l|c|c|c|c|c|c|c|c|c|c|c|c|}
\hline \multicolumn{1}{|c|}{ Month } & 1 & 2 & 3 & 4 & 5 & 6 & 7 & 8 & 9 & 10 & 11 & 12 \\
\hline PRT [h] & 69.5 & 91.8 & 190.2 & 263.4 & 296.1 & 306.8 & 316.8 & 276.1 & 224.4 & 205.1 & 98.3 & 103.9 \\
\hline RT [h] & 62.4 & 84.2 & 182.9 & 260.4 & 295.2 & 305.7 & 314.6 & 274.5 & 223.1 & 204 & 96.1 & 98 \\
\hline T2 or T3 [ $\left.{ }^{\circ} \mathrm{C}\right]^{*}$ & 10.3 & 13 & 18.4 & 30.3 & 33.5 & 35.1 & 42.4 & 41.6 & 30 & 23.7 & 16.8 & 11.1 \\
\hline SY13 [GJ] & 1.29 & 2.03 & 6.68 & 11.78 & 12.33 & 11.65 & 15.03 & 13.09 & 7.97 & 6.87 & 1.99 & 2.13 \\
\hline SY11_15 [GJ] & 1.73 & 3.62 & 8.87 & 11.03 & 12.54 & 12.74 & 14.17 & 12.97 & 8.88 & 6.54 & 2.79 & 1.6 \\
\hline
\end{tabular}

* The average temperature of the currently supplied ST1 or ST2 storage tank.

Source: own study.

components of the thermal installation into account, namely: collectors (ETCHP), solar storage tanks (ST), and copper pipes (Table 2).

TABLE 2. The demand for materials and $\mathrm{CO}_{2}$ emission factors

TABELA 2. Zapotrzebowanie na materiały i wskaźniki emisji $\mathrm{CO}_{2}$

\begin{tabular}{|l|c|c|c|c|}
\hline \multicolumn{1}{|c|}{ Material } & ETCHP & ST & pipe & $\mathrm{CO}_{2}$ emission factor $\left[\mathrm{kg}_{\mathrm{CO}_{2}} / \mathrm{kg}_{\text {material }}\right]$ \\
\hline Copper $[\mathrm{kg}]$ & 418.176 & & 164.6 & 2.711 \\
\hline Steel $[\mathrm{kg}]$ & 929.28 & 990.4 & & 1.487 \\
\hline Glass $[\mathrm{kg}]$ & 542.08 & & & 1.35 \\
\hline Elastomer $[\mathrm{kg}]$ & 154.88 & & & 2.85 \\
\hline Insulation $[\mathrm{kg}]$ & 77.44 & 75.8 & & 1.86 \\
\hline Electrical energy [MJ] & 2361.92 & 475.2 & & 0.226 \\
\hline Natural gas [MJ] & 638.88 & 583 & & 0.063 \\
\hline
\end{tabular}

Source: own work based on (Hill et al. 2012; Greening and Azapagic 2014).

The calculations excluded some of pollutant emissions resulting from e.g. transport, extraction of raw materials, or disposal of the installation after the end of the life cycle. It was considered that these emissions are relatively small, and thus have a negligible impact on the achieved ecological effect.

To minimize the negative ecological impact of supplying the pump-control system with electricity, the use of PV system has been suggested. An analysis of the measurement data on the operation time of the pump of the solar system has shown that the pump operated during periods of no solar radiation. In addition, solar controller requires continuous power supply. It was assumed that the target power supply system is not autonomous but connected to the backup power supply from the power grid. The autonomous system was not analyzed, due to it is usually oversized, and the overriding objective of this study is to minimize $\mathrm{CO}_{2}$ emissions. 
The avoided $\mathrm{CO}_{2}$ emissions resulting from the expansion of the thermal system with the addition of the PV system was estimated from the general formula (2):

$$
\begin{gathered}
\text { reduction of } \mathrm{CO}_{2} \text { emission }=f \text { (electricity produced in the } \mathrm{PV} \text { system, emission during } \\
\text { the production of the system components expressed as equivalent of } \mathrm{CO}_{2} \\
\text { fossil fuel consumption for the electricity production) }
\end{gathered}
$$

During the simulation, the power supply system consists of PV panels arranged at an angle of $45^{\circ}$, an inverter, and batteries connected in a way that prevents the sale of energy to the grid. On the basis of the measurement data regarding the solar system operation and the measured solar radiation over spring and summer period, a calculation model, whose aim has to determine the relationship between $\mathrm{CO}_{2}$ emission reduction, the size of PV panel and battery capacity, was developed using the Matlab computing environment.

The PV panel area and capacity of $12 \mathrm{~V}$ battery were selected according to the following algorithm. The electric power that can be produced at each minute of the calculation period, given the currently assumed PV panel area, is determined on the basis of data on solar radiation, which is multiplied by panel efficiency and panel area. It was assumed that the efficiency of the PV panel and inverter is $14 \%$, and the battery efficiency as well as the efficiency of charging sum up to $80 \%$ (Bortolini et al. 2015). The calculated electric power value is comparable to the energy required for supplying the pump-control system. When the amount of electric power that can be produced is lower than the demand for it, the difference is compared with the battery charge status, which is followed by charging (up to $100 \%$ capacity) or discharging (not below $50 \%$ of the battery capacity). If the demand for electric power exceeds the production of electricity from PV panels and when it leads to the battery discharge dropping below $50 \%$ of the maximum capacity, the system is supplied with energy from the power grid. The reduction in demand for electricity resulting from the use of PV system is determined as the difference between the energy demand and the energy supplied from the power grid. The calculated reduction is converted into the amount of the avoided $\mathrm{CO}_{2}$ emission resulting from the electricity production $\left(\mathrm{Ef}=0.74 \mathrm{kgCO}_{2} / \mathrm{kWh}\right.$ ). What is more, the calculated $\mathrm{CO}_{2}$ emission reduction is diminished by $\mathrm{CO}_{2}$ emission resulting from the production of $\mathrm{PV}$ panels and batteries. It was assumed that the rate of $\mathrm{CO}_{2}$ emission per $1 \mathrm{~m}^{2}$ of PV panel is $160 \mathrm{~kg}$ (Bortolini et al. 2015). With the assumed ratio of $\mathrm{CO}_{2}$ emission related to the battery weight $\left(\mathrm{pl}=1.14 \mathrm{kgCO}_{2} / \mathrm{kg}_{\text {batteries }}\right.$ ) (Schneider Electric 2017), the relationship between the emission and the battery capacity has been determined on the basis of linear regression model (3). This model is based on the battery capacity and the corresponding battery weight (Soltec 2017):

$$
E p a=p 1 \cdot(p 2 \cdot p a-p 3)
$$

where:

$$
\begin{aligned}
& \text { Epa }-\mathrm{CO}_{2} \text { emission produced during battery production }\left[\mathrm{kgCO}_{2}\right], \\
& p a-12 \mathrm{~V} \text { battery capacity [Ah], }
\end{aligned}
$$


$p 2-$ the slope of the regression line, $3.265 \mathrm{~kg}_{\mathrm{bat}} / \mathrm{Ah}$,

p3 - the constant coefficient, $0.387 \mathrm{~kg}_{\text {bat }}$.

It was assumed that the typical service life of the installation is 20 years. Carbon dioxide loads, resulting from the production of the system components, were referenced to a period of 20 years. It was assumed that during this period the batteries will be replaced three times.

\section{Results}

\subsection{The environmental effectiveness of the use of solar installation}

Annually the DHW heating used 82.94 GJ of solar energy thereby saving $2520 \mathrm{~m}^{3}$ of natural gas - calculated for calorific value $37 \mathrm{MJ} / \mathrm{m}^{3}$ (igaz 2019), and gas boiler efficiency $\sim 90 \%$ (Matuszewska 2017). This means a reduction of $\mathrm{CO}_{2}$ emission by $5040 \mathrm{~kg} / \mathrm{year}$. This value must be diminished by the amount of $\mathrm{CO}_{2}$ associated with the demand for electricity of the solar system, amounting to $270.8 \mathrm{kWh} /$ year. Taking into account the efficiency of the energy conversion in power plants, energy losses during the transmission, and the own demand of the power plant, it is required to produce $343.4 \mathrm{kWh}$ of energy. The amount of emitted $\mathrm{CO}_{2}$ in the process is $278.8 \mathrm{~kg}$. When analyzing the environmental effects of the application of the solar system, the production cycle of the most material-consuming components, namely: solar collector, DHW storage tank, and solar collectors, was taken into account. Based on the data from Table 2, $\mathrm{CO}_{2}$ emission for the collector area of $38.72 \mathrm{~m}^{2}$ and the total capacity of storage tanks amounting to $3000 \mathrm{dm}^{3}$ are approximately $6611 \mathrm{~kg}$ of $\mathrm{CO}_{2}$. Taking into account the fact that the solar system will operate for about 20 years, the $\mathrm{CO}_{2}$ emissions can be estimated at a level of approximately $330.5 \mathrm{~kg}$ of $\mathrm{CO}_{2}$ per year.

In order to evaluate the environmental effect of the use of the solar installation, all changes in $\mathrm{CO}_{2}$ emission resulting from the use of natural gas $(-5040.0 \mathrm{~kg} / \mathrm{year})$, electricity ( $278.8 \mathrm{~kg} /$ year), and solar installation (330.5 kg/year), giving a total value of $-4430.7 \mathrm{~kg}$ of CO per year, should be taken into account.

\subsection{Optimization of panel size and battery capacity}

Simulation variants, with different sizes of the area of the panel (ranging from 0 to $3 \mathrm{~m}^{2}$ ) and $12 \mathrm{~V}$ battery capacities (from 0 to $100 \mathrm{Ah}$ ) were considered. The annual environmental effect, expressed in avoided $\mathrm{CO}_{2}$ emissions as a function of the area of the panels and the battery capacity, is shown in Figure 3. 


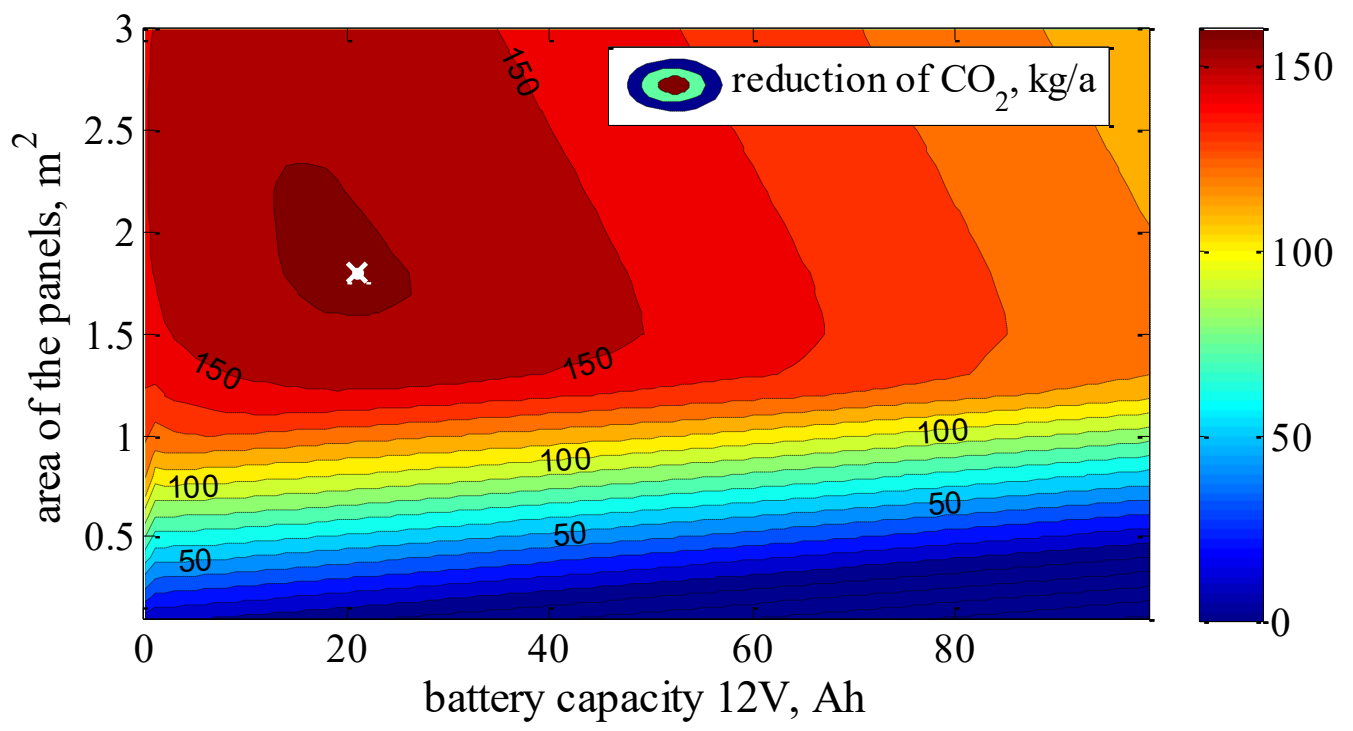

Fig. 3. Annually reduction of $\mathrm{CO}_{2}$ emissions by PV systems as a function the battery capacity and the area of the panels

Source: own study

Rys. 3. Roczna redukcja emisji $\mathrm{CO}_{2}$ przez systemy fotowoltaiczny w zależności od pojemności akumulatora i powierzchni paneli PV

For PV panels area in the range from $0 \mathrm{~m}^{2}$ to approx. $1.2 \mathrm{~m}^{2}$ the $\mathrm{CO}_{2}$ reduction benefits will change linearly. For larger PV panel area, the real impact of the battery, not just the emission resulting from its production, can be observed. The obtained results indicate that in the case of the tested DHW system the best option in terms of $\mathrm{CO}_{2}$ emission is a combination of PV panels with an area of $1.8 \mathrm{~m}^{2}$ and the battery with a capacity of $21 \mathrm{Ah}$.

\section{Conclusions}

Solar installation operating in southeastern Poland, with an area of $38.72 \mathrm{~m}^{2}$ of the absorber, and inclined at an angle of $45^{\circ}$ towards the south, produces $23 \mathrm{MWh}$ per annum. This energy is used to heat DHW. The annual reduction in $\mathrm{CO}_{2}$ emission diminished by $\mathrm{CO}_{2}$ generated during the production of solar collectors or solar storage tank is $4430 \mathrm{~kg}$. The pump-control system of the solar system consumes $343.4 \mathrm{kWh}$ of electricity per year. The addition of the PV installation with an area of $1.8 \mathrm{~m}^{2}$ and the battery with a capacity of $21 \mathrm{Ah}$ will increase the environmental effect by approximately $160 \mathrm{~kg} /$ year. The above calculations also take into account emissions resulting from the production of PV panels and batteries. Minor differences arise from the fact 
that 1 up to $2 \%$ of solar yields in the form of electricity is used for the operation of the thermal installation. The obtained values of the possible $\mathrm{CO}_{2}$ emission reduction are determined by emission factors characteristic for the Polish energy sector.

\section{References}

BBN 2012. Analysis of electric energy losses in Polish power distribution (Analiza nt. wielkości strat $w$ przesyle energii elektrycznej $w$ Polsce). [Online] www.bbn.gov.pl/download.php?s=1\&id=12037 [Accessed: 2016-11-15] (in Polish).

Bortolini et al. 2015 - Bortolini, M., Gamberi, M., Graziani, A. and Pilati, F. 2015. Economic and environmental bi-objective design of an off-grid photovoltaic-battery-diesel generator hybrid energy system. Energy Conversion and Management (106), pp. 1024-1038.

Carotenuto et al. 2017 - Carotenuto, A., Figaj, R.D. and Vanoli, L. 2017. A novel solar-geothermal district heating, cooling and domestic hot water system: Dynamic simulation and energy-economic analysis. Energy (141), pp. 2652-2669.

Energo-therm. PV. (Energosol) (Ekologiczne systemy solarne). [Online] http://www.energosol.pl/oferta_fotowoltaika_moduly_fotowoltaiczne.html [Accessed: 2016-12-12] (in Polish).

Gawlik, L. eds. 2013. Coal for Polish energy sector in 2050 perspective - scenario analysis (Wegiel dla polskiej energetyki w perspektywie 2050 roku - analizy scenariuszowe). Katowice (in Polish).

Greening, B. and AzApagic, A. 2014. Domestic solar thermal water heating: A sustainable option for the UK? Renewable Energy 63, pp. 23-36.

Hill et al. 2012 - Hill, N., Brannigan, C., Wynn, D., Milnes, R., van Essen, H., Den Boer, E., van Grinsven, A., Ligthart, T. and van GijlswiJk, R. 2012. The role of GHG emissions from infrastructure construction, vehicle manufacturing, and ELVs in overall transport sector emissions. [Online] http:// www.eutransportghg2050.eu/cms/reports/ [Accessed: 2016-12-12].

igaz.pl: Calorific value of gas compared to other energy carriers (igaz 2019) (Wartość opałowa gazu w porównaniu do innych nośników energii). [Online] https://www.igaz.pl/index.php?i19,wiedza-parametry-gazu [Accessed: 2019-12-12] (in Polish).

Institute for Renewable Energy (IEO), Association of Employers of the Renewable Energy Forum (ZP FEO). 2013. The Development Plan for Microgeneration for Poland based on Renewable Energy Sources until 2020. Warszawa. [Online] https://pl.boell.org/sites/default/files/the_development_plan_ for_microgeneration_res_poland.pdf[Accessed: 2017-01-13].

Matuszewska et al. 2017 - Matuszewska, D., Kuta, M. and Górski, J. 2017. Cogeneration - development and prospect in Polish energy sector. E3S Web of Conferences 14.

MirowsKi, T. 2016. Utilization of biomass for energy purpose versus reduction of emission of air pollutants from municipal and households sector. Rocznik Ochrony Środowiska 18(1), pp. 466-477.

The National Center for Emissions Management 2015. Emission factors of pollutants from small combustion installations $<50$ MWth. IOŚ-PIB: Warszawa (in Polish).

The National Center for Emissions Management 2019. Emission factors in [kg / MWh] for final consumers of electricity. [Online] https://www.kobize.pl/uploads/materialy/materialy_do_pobrania/wskazniki_emisyjnosci/Wskazniki_emisyjnosci_grudzien_2019.pdf [Accessed: 2019-12-30] (in Polish).

OlCZAK, P. and ZabaGlo, J. 2015. The efficiency of the solar system with Heat Pipe collectors in apartment building (Efektywność pracy instalacji solarnej z kolektorami Heat Pipe w budynku wielorodzinnym). Cieplownictwo, Ogrzewnictwo, Wentylacja 11(46), pp. 427-431 (in Polish). 
Schneider Electric 2017. Lifecycle Carbon Footprint Analysis. [Online] http://www.apc.com/salestools/ VAVR-9KZQVW/VAVR-9KZQVW R0 EN.pdf [Accessed: 2017-01-03].

Soltec 2016. Battery power (Moc baterii). [Online] http://www.soltec.sklep.pl/akumulatory-gel-c-21_23. html [Accessed: 2016-12-12] (in Polish).

SorneK et al. 2018 - SorneK, K., FILIPOWICZ, M. and JASEK, J. 2018. The Use of Fresnel Lenses to Improve the Efficiency of Photovoltaic Modules for Building-integrated Concentrating Photovoltaic Systems. Journal of Sustainable Development of Energy, Water and Environment Systems 6(3), pp. 415-426.

Statistics Poland 2019. Energy Statistics 2017 and 2018 (Gospodarka paliwowo-energetyczna w latach 2017 i 2018). [Online] https://stat.gov.pl/en/topics/environment-energy/energy/energy-statistics-in2017-and-2018,4,14.html [Accessed: 2020-03-07] GUS: Warszawa (in Polish).

Piotr Olczak, Małgorzata OleK, Dominik Kryzia

\section{Ekologiczny wpływ zastosowania instalacji footermicznej i fotowoltaicznej do przygotowania ciepłej wody użytkowej}

\section{Streszczenie}

W budynku wielorodzinnym położonym w południowo-wschodniej części Polski, zamieszkałym przez 105 osób, zmodernizowano system przygotowania ciepłej wody użytkowej. Istniejący system grzewczy ( 2 kotły gazowe) został rozbudowany o układ kolektorów słonecznych składający się z 32 próżniowych kolektorów rurowych (powierzchnia absorbera wynosi $38,72 \mathrm{~m}^{2}$ ). Na podstawie danych o wydajności systemu oszacowano ekologiczny efekt modernizacji, wyrażony jako uniknięta emisja $\mathrm{CO}_{2}$. Zastosowanie systemu kolektorów słonecznych pozwala zmniejszyć emisję $\mathrm{CO}_{2}$ do $4,4 \mathrm{Mg}$ rocznie. Analizując skutki środowiskowe zastosowania instalacji kolektorów słonecznych, wzięto pod uwagę cykl produkcyjny najbardziej materiałochłonnych komponentów instalacji, a mianowicie zasobnika ciepłej wody użytkowej i kolektorów słonecznych. Aby jeszcze bardziej ograniczyć emisję $\mathrm{CO}_{2}$, zaproponowano instalację fotowoltaiczną, dostarczającą energię elektryczną do napędu pompy obiegowej instalacji kolektorów słonecznych.

W środowisku obliczeniowym Matlab, na podstawie danych pomiarowych z instalacji kolektorów słonecznych i danych pomiarowych całkowitego natężenia promieniowania, zoptymalizowano powierzchnię paneli fotowoltaicznych i pojemność akumulatorów. Wykazano, że układ paneli fotowoltaicznych o powierzchni ok. $1,8 \mathrm{~m}^{2}$ oraz akumulatorów $12 \mathrm{~V}$ o pojemności ok. 21 Ah zapewnia największy efekt ekologiczny w postaci najniższej emisji $\mathrm{CO}_{2}$. Dodanie paneli fotowoltaicznych może zmniejszyć roczną emisję $\mathrm{CO}_{2}$ nawet o dodatkowe $160 \mathrm{~kg}$. Powyższe obliczenia uwzględniają również emisje wynikające $\mathrm{z}$ tytułu produkcji paneli fotowoltaicznych i akumulatorów.

SŁOWA KLUCZOWE: panel fotowoltaiczny, redukcja emisji $\mathrm{CO}_{2}$, próżniowe kolektory rurowe typu heat pipe 